\title{
Confucian friendship (You 友) as spousal relationship: a feminist imagination
}

\author{
Li-Hsiang Lisa Rosenlee ${ }^{1}$
}

Received: 25 August 2015/Revised: 4 November 2015/Accepted: 5 November 2015/

Published online: 18 November 2015

(C) Academy for International Communication of Chinese Culture and Springer-Verlag Berlin Heidelberg 2015

\begin{abstract}
This paper intends to propose a hybrid conceptual paradigm incorporating both Confucian you 友 and Greek philia to replace the spousal relationship. So in response to the question of "What is a spouse for?" the answer is friendship. And in rethinking spousal relationship as a hybridized Confucian you 友 with a blend of Greek philia, the functionary and oppressive aspects of marriage are thus made incompatible with this friendship based marital union. At the same time, by incorporating marital relationship into friendship, the concept of friendship is made ever more perfect. Just as in a good marriage both spouses are lifted up by their marital union, the union between marriage and friendship uplifts both conceptually as well. Spouses, in short, should be best friends who lead one another to moral goodness through mutual cutting and polishing one's critical moral sense with penetrating understanding and enduring faith, and the spousal relationship, in turn, is also the best friendship that is perpetual and complete in its form and content by building a truly shared life with all aspects of human capacities, eros and all. In short, a feminist marriage should be a marriage of moral friendship and passionate love. It is a new conceptual paradigm of marriage that is made in a Confucian image for feminists; it is also a practical feminist paradigm that we mortals can strive for and realize in our human all-too-human life.
\end{abstract}

Keywords Confucian friendship - Greek friendship - Spousal relationship · Feminism $\cdot$ History of friendship

Li-Hsiang Lisa Rosenlee

lihsiang@hawaii.edu

1 University of Hawaii - West Oahu, 91-1001 Farrington Highway, Kapolei, HI 96706, USA 


\section{Introduction}

Marriage along with the role of wife and mother has long been a subject of considerable discussion within the feminist communities with some advocating a "philosophy of evacuation," or a complete abolition of the legal institution, which to many is the root of female servitude and her continuous affliction (Allen 1984/1993; Okin 1989; Card 1996, 2002, 2007). Women's subjection in the institution of marriage is well documented (Yalom 2001). Well into the mid-19th century after the abolition of legal slavery on both sides of the Atlantic Ocean, by law, women were still subject to their husband's authority. As John Stuart Mill impassionedly writes in The Subjection of Women, "Marriage is the only actual bondage known to our law. There remain no legal slaves, except the mistress of every house" (Mill Mill 1869/2003, p. 348).

Even with all the political, legal and social gains in recent history, women continue to suffer at the hand of the marriage institution. The uphill battles that women have to fight are paramount and are further compounded by the duty of child-rearing and household management. Numerous sociological studies from The Second Shift (1989), The Price of Motherhood (2001/2010), to Lean In (2013) illustrate the difficulties of combining work and family even for highly educated, successful and wealthy women. The role of wife and mother continue to define the essence of female identity and hence the burden of child care and household management continues to hamper women's achievement; the issue of combining family and work is still very much a uniquely woman's issue despite all the social gains in pushing for equal parenting and partnership in marriage. The social sentiment that a woman's first call of duty is the household regardless of what else that she might also choose to do explains the persistent achievement gap between genders. Now more women than men are in college and about half of the medical as well as law degrees are awarded to women (Time Oct. 14 2009); yet women only account for $36 \%$ of both the lawyers/judges and the medical doctors (New York Times Sept. 30 2012), not to mention only about $4 \%$ of the CEOs in the Fortune 500 are women! (CNN March 24 2015)

So given all these, is it still possible or even worthwhile for feminists to rehabilitate the institution of marriage? Or, as Allen (1984), Okin (1989), and Card $(1996,2002,2007)$ argue, the best course of action for feminists is to recognize that motherhood and marriage are by nature oppressive to women and should be left behind as a remnant of the patriarchal past. If Allen's pronouncement of motherhood as the death of women, and Card's advocacy of the abolition of marriage institution seem extreme as well as impractical, given that far from being abolished the marriage institution with the Supreme Court's historic ruling in Obergefell v. Hodges is now further expanded to same-sex couples in all 50 states (Obergefell v. Hodges 2015), what then would be a more productive way for feminists to re-conceptualize marriage for those who opt to enter a legal union with another consenting adult for life while at the same time dealing with the oppressive aspects of marriage that continue to impede women's ability to flourish? If one takes away the long standing belief in women's natural inferiority and the economic 
necessity for women to seek male protection and guardianship, then for what does one get marry? That is to say, if women no longer are compelled to marry for money, protection, or social conformity, then what are the unique goods that one gets from marriage? Furthermore, if one takes away the long standing church teaching of childbearing and rearing as the natural purpose of marriage, then what is it that holds marriage together to supposedly last for a life time, till death do we part? In short, one might ask: what is a spouse for?

In the following, I intend to explore the possibility of using a hybrid concept of friendship incorporating both Greek philia and Confucian you 友 to re-conceptualize modern spousal relationship and thereby rehabilitate the institution of marriage to enable women to live a fully flourishing life while sidestepping the pitfalls of absolute equality. First, we will begin with the concept of "perfect friendship," the most intimate and highly praised relationship between male peers as traditionally conceived in the history of western philosophy. In many ways, the union of modern marriage, a perfect medium through which strangers are made into family by forming an insoluble bond, resembles the union in perfect friendship. However for the most part in the history of western philosophy, only men are seen as capable of forming this sort of eternal relationship with mutual melting of two souls into one.

\section{A history of friendship: From Plato to Kant}

The concept of "perfect friendship," most famously articulated by Aristotle, undoubtedly is conceptualized between two social equals and is reserved for male peers only. But the Greek concept of philia diverges significantly from our modern conception of what is entailed in "friendship". For Aristotle, philia applies not only to social equals, but also to unequal familial relationships such as father-son, husband-wife, and brothers as well as to contractual relationship in commerce and in political citizenship/association (Nicomachean Ethics Book 8; Eudemian Ethics Book 7; Rhetoric Book 2; Politics Book 2 \& 3; Magna Moralia Book 2; cf. trans. Barnes 1984; Nussbaum 1986, p. 354; Sherman 1997, p. 199; Sim 2007, p. 195; Salkever 2008, pp. 75-76; Connolly 2012, p. 72). Throwing into this wide-ranged mix of mutually beneficial relationships covered under the umbrella of "philia" is Plato's erotic philia where friends are first and foremost understood as an erotic attachment between two lovers (Lysis; Phaedrus; Symposium; Alcibiades; Law Book 8; cf. trans. Cooper 1997; Fuller 2008, p. 201; Nicoles 2009, Chap. 4; Murr 2014, p. 3). The eroticism under discussion however is primarily limited to males only in keeping with ancient Greek's pederastic tradition. Marital relationship between the sexes doesn't even come close to the discussion of the blessed friendship between two male lovers who are given a head start in their winged ascendant to Olympus after death, a divine gift unparalleled to what one might get from non-lover friendships (Phaedr. 256a7ff).

Now by re-conceptualizing martial relationship in terms of friendship, one might say that it is not so much of an invention as more of a revitalization of what came before in the forgotten tradition where erotic attachments and familial relationships, far from being antithetical or an impediment to a long-lasting friendship, is in fact 
conceptually compatible with, if not the origin of, friendship. But what is new here is that the hybrid form of friendship incorporating both Greek philia and Confucian you 友 will now be applied to martial relationship replacing the patriarchal authority in matrimony and at the same time sidestepping the pitfalls of absolute equality, and thereby providing women a new set of conceptual tools to navigate through the contour of the eternal marital bond.

"Perfect friendship" (NE 1156b7ff) as Aristotle understands it, is a friendship of virtue; that is, the philos is loved on the ground of virtue as opposed to utility or pleasure (NE 1156a14ff; EE 1239a1ff). And perfect friendship is only possible between two symmetrically similar men in their virtuous character as well as social status. As Aristotle repeatedly stresses, equality is the mark of friendship ( $N E$ $1157 \mathrm{~b} 32 \mathrm{ff}, 1158 \mathrm{~b} 26-32,1159 \mathrm{~b} 3$; EE 1238b15-25, 1240b1-2). After all, a friend is another self ( $N E$ 1166a31-32, 1170b6; EE 1245a29ff); that similitude between one's self and one's true friend is not just in a figurative sense, but literal as well. This is so, because as Aristotle understands it, friendship proceeds from a man's relations to himself and his love for his friend "is linked to one's love for oneself" (NE 1166a131, 1171b32-33; EE 1240b1ff). This required similitude, not to mention the assumed natural inferiority of woman as articulated by Aristotle in various writings (Generation of Animals; Politics; cf. Mahowald 1978/1994, pp. 22-31), obviously excludes woman right out of hand from forming perfect friendship with man by becoming his second self whom he loves truly and consistently as he loves himself.

Although friendship for Aristotle also applies to martial relationship, it is a friendship of a different sort-friendship based on utility and pleasure (EE 1239b2427, 1242a31-32; NE 1162a16-25). However in one passing remark, Aristotle does briefly mention the possibility of martial relationship based on virtue, if both parties are good (NE 1162a25-26); but clearly for Aristotle, due to women's inherently inferior nature and flimsy rationality, the sort of virtues that women are capable of would be different in kind from the ones conventionally applied to men. Women's virtue lies in obedience and submission. As Aristotle repeatedly analogizes the marital relationship between the husband and wife as akin to the ruler-subject ( $E E$ $1238 \mathrm{~b} 15-25)$ in the political constitution of aristocracy (EE 1241b29-32; NE 1160b33-35); there should be no doubt as to who is the one rules and the other obeys. Perfect friendship is thereby imaged as between two good men, literally.

Perfect friendship, although it is based on virtue, is not entirely limited to intellectual pursuits; the degree of intimacy that Aristotle requires of this sort of true friendship is extensive and in many aspects resembles marital intimacy. Besides having equal excellence and mutual good will, true friends also wish to live and die together, delight in each other's company and share things in common including taste, joy, and sorrow (EE 1240b5-13; NE 1166a3-8). By living and dying together, Aristotle doesn't mean causal association; Aristotle's "living and dying together" means a thorough sharing of all aspects of human experiences and activities with one's philos, in both intellectual and mundane activities. Sharing is the key and one wishes to share all things in common with one's philos, which is another self. As Aristotle writes, "For friendship is a partnership, and as a man is to himself, so is he to his friend... And whatever existence means for each class of men, whatever it is for whose sake they value life, in that they wish to occupy themselves with their 
friends; and so some drink together, others dice together, others join in athletic exercises and hunting, or in the study of philosophy, each class spending their days together in whatever they love most in life; for since they wish to live with their friends, they do and share in those things as far as they can" (NE 1171b32-1172a8). Philosophical contemplation is only one among many activities that one shares with one's philos. And who could be more intimately sharing all aspects of life experience with one's self than one's spouse, with whom one is supposed to unite into one everlasting, single soul till death do we part?

Spousal relationship would have been the best form of philia, if not for the alleged female inferiority that Aristotle attributes to women. Indeed as Martha Nussbaum reflects on the shortcomings of Aristotle, "If he had not had his views about female inferiority, he would every likely have preferred this sharing to extend into the sphere of the household as well: thus an even more perfect philia would be a good marriage, in which the full range of the aspirations and concerns that make up a human life might be accommodated" (358). In short, Aristotle's prefect friendship in which "true friends are a single soul" ( $E E$ 1240b2) would have been more perfectly realized in marital relationship, an everlasting unity sharing all aspects of human experience both intellectual and mundane, in good times and bad, in sickness and health, and for better or worse.

What is more is that in marital friendship, the neglected aspect of eros by Aristotle in the discussion of philia can thus be recovered. The absence of eros in Aristotle's writings is an obviously subjective omission, given how prominently eros figures in Plato's numerous writings (Lysis; Phaedrus; Symposium; Alcibiades; Law Book 8; cf. Nussbaum 1986, pp. 370-371). The trouble with eros as Aristotle sees it, apart from his own subjective inclination, is that it overwhelms prohairesis (Salkever 2008, p. 73). But for Plato, it is precisely the madness of eros that enables us to transcend our human limitations. Erotic attachment, as Plato sees it, is the beginning of a long-lasting friendship; without that intense erotic desire first drawing two souls together and merging them into one unitive love, non-lover philia remains hollow, lacking that awe-inspiring divine madness shown in erotic friendship (Phaedr. 256a7ff).

Uncharacteristically, Socrates, who professes his own ignorance on nearly all subjects, boasts his god-given expertise at love. As he says to Hippothales who blushes at the questions of who is the best looking boy in the opening of the dialogue of Lysis, a dialogue on friendship, "Aha! You don't have to answer that...I can see that you are not only in love but pretty far gone too. I may not be much good at anything else, but I have this god-given ability to tell pretty quickly when someone is in love, and who he's in love with" (Lys. 204b5-c2). And again in Phaedrus, Socrates states his expertise at love as a divine gift to him (Phaedr. 257a5-b2). If one takes what Socrates says at its face value, then obviously eros is an important philosophical subject that Socrates claims expertise at and is integral to the concept of philia. Even though the sort of eros as well as philia under discussion is decisively directed at males, the centrality of erotic philia in Plato helps reorient our modern concept of both friendship and marital relationship. 
Marital relationship, among other things, is also sexual in nature, and as Plato has taught us, erotic attachment is neither different in kind nor an impediment to a longlasting philia of virtue. In fact, erotic friendship inspired by divine madness surpasses all other kinds of friendship. As Socrates says in his second speech offered as a palinode for his earlier speech in praise of non-lover friendship to beg for god's forgiveness, once the beloved comes of age and accepts the lover he realizes that "all the friendship he has from his other friends and relatives put together is nothing compared to that of this friend who is inspired by a god" (Phaedr. 255b6-8). Erotic friendship between lovers is hence of the highest kind of philia. Non-lover friendship as Socrates explains, "is diluted by human self-control; all it pays are cheap, human dividends, and though the slavish attitude it engenders in a friend's soul is widely praised as virtue, it tosses the soul around for nine thousand years on the earth and leads it, mindless beneath it" (Phaedr. 256e3-257a2). For Plato, eros, a divine gift, in a sense, ennobles the mere human bond; a lover's god-inspired madness for the beloved itself becomes awe-inspiring.

Eros, as Socrates explains, is an unreasoning, overwhelming desire to take pleasure in the beauty of human body (Phaedr. 238b9-c4). There is a sense of involuntariness when it comes to our love of beauty; our sight is intuitively drawn to physical beauty, since as Socrates says our sight is the sharpest of our senses and beauty is the most visible among all objects (Phaedr. 250d1-8). Our love of physical beauty in time should give way to our love of beautiful wisdom as lovers come together to help deliver beautiful ideas from their pregnant souls by living a blessed philosophical life (Sym. 206dff; Phaedr. 256a7-b5). But first each lover seeks out his beloved after his own fashion, and nurtures and worships the beloved like a god. It is with our love of physical beauty that we begin our journey into our love of the soul. Eye, as Socrates sees it, is the natural gateway into the soul (Phaedr. 255c6-d1); it is through the eye that the lover's desire for the beloved overflows from the lover's into the beloved's soul and the beloved then fills love in return, as if the beloved has caught "an eye disease" (Phaedr. 255d5). The beloved's return of love is called "backlove," which the beloved "neither speaks nor thinks of it as love, but as friendship" (Phaedr. 255de1-2). In other words, the friendship bond between the lover and the beloved becomes established when love is reciprocated through the mirror-image of the beloved himself in the lover's eye. Love, then, is contagious spreading from the lover to the beloved; the beloved then loves the lover in return through the mirror image of himself in the lover or backlove. This sort of reciprocating act of love and backlove is the closest to the melting of two individuals into one unitive love as one can possibly get. To a modern reader, Plato's account of erotic philia, no doubt, brings to mind the deepest sense of romanticism in a sexual relationship where lovers long to merge with one another in an endless stream of reciprocating love and backlove.

Whether Plato sanctions actual physical consummation between the lovers is beside the point; for instance, contrary accounts can be found in Phaedrus (256c7e2) and Law (836c3-6) (cf. Murr 2014, pp. 3-34). However eroticism in Plato's account of the highest philia is unmistakable. For Plato, philia belongs to the lovers who begin with the desire of physical consummation and end with the consummation of their souls in a blessed, philosophical life. Aristotle's omission of eros 
from his exhaustive account of philia, unfortunately, sets the tone for the subsequent philosophers who see eros as irrelevant, if not diametrically opposed, to true philia. Especially, after the effect of Christianization, eros now belongs only to the sexual relationship between the sexes. This separation of eros and philia, among other things, also means that spouses will never be the sort of friends that two men can possibly be since eros always stands in the way. And erotic relationship between the sexes as the subsequent philosophers, such as Aquinas, Montaigne, and Kant, theorize stands far below the long cherished true philia.

At most, erotic philia, far from its glorious days of Plato as the highest form of philia, is now limited to the sexual relationship between the sexes legitimized by marriage. And following Aristotle, the subsequent Christian tradition often times analogizes marriage as a friendship of pleasure or utility (cf. Fullam 2012, p. 667). In other words, marriage is a medium through which certain functional utilities are realized, and erotic, sexual pleasure is one among them. However, erotic love has long been seen as morally problematic by Church fathers such as Augustine and Aquinas due to its unpredictability and irrational nature, and it is also associated with the disorderly desire that led to the fall of humanity (cf. Ruether 2000; McLaughlin 2000). In fact for Augustine, celibacy, not the sexual union of marriage, is the higher path to sacramentum for Christians and a sexless marriage to Augustine is the most praiseworthy (Fullam 675-676). So even within the context of marriage, erotic love is still deemed as problematic. For both Augustine and Aquinas, there are only two ways to render sex morally and spiritually permissible: to procreate or to pay the "conjugal debt" (Fullam 682). To speak of marital sex as a debt, it brings to mind the transactional nature of matrimony where it is generally understood that in exchange for financial support and security, the wife promises, among other things, sexual access. After all, not until1993, marital rape was legal; as the often cited 17th century English court opinion states, in consenting to marriage the wife is understood as having given herself to the husband, a promise that she cannot retract (Mahoney and Williams 1998, p. 4). So in this social context, who is the debtor and who is the debtee seem quite clear. Erotic love itself is sinful except when it serves some definitive purposes in marriage: to procreate or to pay the marital debt.

In fact, not just eros is problematic for Christians, the Greek concept of philia is also deemed as incompatible with the theological virtue of charity. The preferential love of Greek philia is seen as antithetical to the indiscriminating nature of Christian love where God "causes the sun to rise on the good and the evil and sends the rain on the just and the unjust" (Matthew 5:45; cf. Schindler 140). However Aquinas is one of the few exceptions seeing the compatibility between Aristotelian philia and the theological virtue of charity (cf. Quinn 1996; Schwartz 2007; Schindler 2008). At its face value, charity - a fellowship of God and man-runs counter to Aristotelian philia of equal virtue and standing. In fact, for Aristotle, when the disparity is so great, friendship becomes unsustainable and the friendship between god and man is of such nature: "This becomes clear if there is a great interval in respect of excellence or vice or wealth or anything else between the parties; for then they are no longer friends, and do not even expect to be so. And this is most manifest in the case of the gods; for they surpass us most decisively in all good 
things" (NE 1158b32-1159a1). Indeed some heavy conceptual maneuvering is required to fit Aristotelian philia into the theological box of charity. Nevertheless, Aquinas sees values in preserving the intimate partiality of philia while transcending its exclusivity to better align with the Christian theological virtue of charity.

Unlike Aristotelian philia as among the greatest external goods that we can acquire (NE 1169b10; EE 1234b33), charity is not something that we can obtain through human effort, nor is it a natural phenomenon. Rather, charity is a divine grace, an infused virtue, given by God, and our participation in that divine love for us is charity (Summa Theologiae II-II. 23-26; cf. trans. Pakaluk 1991, pp. 171-184; Quinn 274; Schindler 148). Our gratitude for that divine grace then is extended to all rational human beings who participate in the love for God. The sinner and the faithful, the wicked and the good alike, we love them by virtue of our love for God who loves all indiscriminately. However in loving others, that is, one's neighbor, Aquinas seeks to incorporate Aristotle's intimate partiality where one loves one's philos more intensely. Aquinas justifies that partiality by quoting Leviticus 20.9 that transgression against some is a more grievous sin than others such as one's father and mother (ST II-II.26.6; Pakaluk183). As Aquinas reasons, in wishing others well, all are equal, that is, we wish all the everlasting happiness, but in action, partiality is permitted since we cannot do good to all equally (ST II-II.26.6; Pakaluk184). Thus, we ought to love those who are closer to us more than others.

Love, for Aquinas, is divided into the love of concupiscence and the love of friendship. The former seeks to obtain the good for oneself, whereas the latter seeks the good for another. And hence "the love of friendship is loved simply and for itself; whereas...the love of concupiscence, is loved, not simply and for itself, but for something else" (ST I-II.26.4; Pakaluk155). It is not surprising that spousal love falls under the love of concupiscence. As Aquinas uses the possessive nature of the husband over his wife as an example for the love of concupiscence: "For in love of concupiscence he who desires something intensely, is moved against all that hinders his gaining or quietly enjoying the object of his love. It is thus that husbands are said to be jealous of their wives, lest association with others prove a hindrance to their exclusive individual rights" (ST I-II.28.4; Pakaluk168). This possessive, marital love of concupiscence then is put in contrast with the higher kind of love, the love of friendship where a man is zealous on behalf of his friend, to repel all that stands in the way of the friend's good (ST I-II.28.4; Pakaluk168). It seems that once again the purer type of love of mutual good will where the beloved is loved simply and for itself belongs to someone else other than a woman who is after all only an object of enjoyment, an object over which the husband has an exclusive claim.

Despite Aquinas's tremendous theoretical maneuvering, as pointed out earlier, for the most part in the Christian tradition, both philia and eros are seen as pagan vices confusedly disguised as virtues. As Kierkegaard says loud and clear, both eors and philia are passionate preferences, a form of self-love contrary to the truth of the Christian teaching of charity, love of neighbor: "Just as self-love centres exclusively about this self-whereby it is self-love, just so does erotic love's passionate preference centre around the one and only beloved and friendship's passionate preference around the friend. The beloved and the friend are therefore called, remarkably and significantly enough, the other-self, the other-I-for one's neighbor 
is the other-you, or more accurately, the third-man of equality" (Works of Love; Pakaluk 241). In other words, the sort of exclusive devotion praised in eros and philia is essentially self-preferential: it is my beloved and my philos who is my second self that I have devoted myself to. In contrast, the Christian virtue of charity is non-self-preferential or what Kierkegaard calls "self-renunciation's love" (239). The long cherished pagan goods of eros and philia for Kierkegaard are really just "glittering vices" (241) with poetic contradictions. And for Kierkegaard it is important for Christians to be clear about what is or is not Christian, instead of confusingly upholding everything-what is also non-Christian. One must make a decision: it is a choice of "either-or," since it would be talking non-sense to have it both ways. Kierkegaard compares that "both-and" with the shopkeeper's dishonesty and foolishness: "Concerning relationships of the spirit, one cannot—if one wants to avoid talking foolishly - talk like a shopkeeper who has the best grade of goods and in addition a medium grade, which he can also highly recommend as being almost as good" (236). Supposedly Kierkegaard could levy this charge against Aquinas who painstakingly infuses Christian charity with the Aristotelian, pagan blend.

Now with the rise of the Christian theological virtue of charity, as Kierkegaard puts it, philia and eros have been thrusted "from the throne" (235). What then is left of friendship? Unlike Aristotle's perfect philia that presupposes a civic life with shared values or Plato's erotic philia that is integral to the blessed philosophical life, the concept of friendship in the modern world is relegated to the realm of personal affairs, a rare private oasis in the midst of the hostile world of constant deceit and betrayal. For instance, for both Montaigne and Kant, friendship is now valued not so much for its virtuosity integral in the shared, good life; rather friendship is seen as a private place of complete trust, communion, and tranquility away from the turbulence in the everyday dealings. Friendship becomes something extra, segregated from the public realm, and nearly impossible to obtain through one's conscious effort.

True friendship indeed is a rare find, so rare that Montaigne's highest friendship, though it builds on Aristotle's perfect philia, now takes on an ineffable, mysterious origin (Fuller 2008). It is a sort of friendship that cannot be intentionally sought; it is found only with gratuitous serendipity. As Montaigne writes in reflecting on his own friendship with Etienne de la Boetie, "So many coincidences are needed to build up such a friendship that it is a lot if fortune can do it once in three centuries" ( $O f$ Friendship; Pakaluk188). It is a friendship of perfect blending of two souls beyond rational explanation: "In the friendship I speak of, our souls mingle and blend with each other so completely that they efface the seam that joined them, and cannot find it again. If you press me to tell why I loved him, I feel that this cannot be expressed, except by answering: Because it was he, because it was I" (192). That ineffable nature of Montaigne's highest friendship is a clear departure from all previous accounts of true friendship that is thought to be the most precious, but is not something beyond our conscious making; friendship, whether its madness is inspired by the gods or not, is squarely a human phenomenon, an attainable external good. Montaigne's ineffable friendship with a mysterious origin is more than just something extraordinary; true friendship now is fated only for the most fortunate chosen few. 
True friendship offers as it were a refuge from that ever present danger in the public dealings. However that rare tranquility is not to be sought within the household. As is true for all previous thinkers, for Montaigne, to build an intimate bond of friendship with a woman is impossible: "Besides to tell the truth, the ordinary capacity of women is inadequate for that communion and fellowship which is the nurse of this sacred bond; nor does their soul seem firm enough to endure the strain of so tight and durable a knot" (190). So one might say, for Montaigne, martial friendship is a contradiction in terms. Furthermore, for Montaigne, marriage is essentially a contractual transaction whereas friendship is its own end: "As for marriage, for one thing it is a bargain... and a bargain ordinarily made for other ends. ... whereas in friendship there are no dealings for business except with itself" (190). Marriage for all practical purposes is business dealing and its defined obligations are antithetical to the intrinsic good of true friendship. By contrast, friendship is a result of free will, not obligation: "And our free will has no product more properly its own than affection and friendship" (189).

As is well known, the sort of raw, transactional nature of marriage is vividly delineated in Kant's definition of sexual union under the "Doctrine of Rights" in the Metaphysics of Morals as "the reciprocal use that one human being makes of the sexual organs and capacities of another" and when the sexual union is accordance with the law, it is called marriage, "that is, the union of two persons of different sexes for lifelong possession of each other's sexual attributes. The end of begetting and brining up child may be an end of nature..." (MM/DR 6:277; cf. trans. Gregor 1996). To Kant, monogamous, heterosexual marriage is the only context in which the enjoyment of sexual pleasure is consistent with morality. For marriage is a legally enforceable contract in which each surrenders one's whole person to the other to use sexually in accordance with "pure reason's laws of right" (MM/DR 6:277-78), and should unfaithfulness arises, one has the right to retrieve one's spouse, "just as it is justified in retrieving a thing" (MM/DR 6:278). This reciprocal equality is essential in ensuring the moral personality of one's own person while engaging in sexual activity with another.

But the emphasis on the equal possession of sexual attributes in marital relationship doesn't lend itself to gender equality. As is true with Aquinas, Kant sees gender hierarchy as integral to matrimony. Immediately after his insistence on the principle of equality in marriage contract where each has an equal possession of the other, Kant makes an exception for spousal domination based on the natural superiority of man: "...for the law to say of the husband's relation to the wife, he is to be your master (he is the party to direct, she to obey): this cannot be regarded as conflicting with the natural equality of a couple if this domination is based only on the natural superiority of the husband to the wife in his capacity to promote the common interest of the household, and the right to direct that is based on this can be derived from the very duty of unity and equality with respect to the end" (MM/DR 6:279). This is so because the insolubility of a union, as Kant reasons, hangs on superiority: "one partner must yield to the other and, in turn, one must be superior to the other in some way, in order to be able to rule over or govern him" (Anthropology 303; cf. trans. Louden 2006). In other words, gender hierarchy is integral to the unity of will in marriage. 
Given the disparate character of the sexes, it is not surprising that for Kant friendship is out of reach of women. Friendship that "has mainly the character of the sublime" is in contrast with "the love between the sexes, that of the beautiful" (Obs. 52; cf. trans. Goldthwait 1960). Much like Montaigne's ineffable, true friendship, Kant's friendship is one of the sublime and the eternal. Furthermore, just like Montaigne's critique of the insoluble nature of marriage as an imitation of the true union in friendship, Kant's unity of will belongs to friendship much more than to marriage: "In friendship, we might say, the unity of the persons...is still more perfectly present, and with more equality, than in marriage" (as quoted in Papadaki 2010 , p. 289; cf. Denis 2001, p. 14). At the end of the day, marriage for Kant is a union of two unequals, pale in comparison with the true union of two equals in friendship.

But unlike Montaigne's true friendship that with sufficient good fortune one might be bestowed on, Kant's highest friendship_-perfect friendship -is an unattainable, transcendent idea; it is a necessary idea in ethics that one should strive for and is commanded by reason as a duty of virtue, but it has no empirical basis, for empirical examples of friendship "are extremely defective" (Lectures on Ethics; cf. trans. Infield 1930/1963, 202). "Friendship (considered in its perfection)" as Kant defines it under the "Doctrine of Virtue" in the Metaphysics of Morals, "is the union of two persons through equal mutual love and respect" (MM/DV 6:469470), but friendship "thought to be attainable in its purity or completeness... is the hobby horse of writers of romances" (MM/DV 6:470), an opinion that Kant holds early on in the opening of his lecture on "Friendship" (LE 200). Kant's cynicism toward true friendship is palpable. And the reason is that the realization of the perfect mutuality of equal love and respect is impossible. The difficulties are numerous, ranging from the delicate balance between love, the power of attraction, and respect, the power of repulsion; the actual reciprocation of equal love and equal respect; and the risk of loss of love or respect when criticize or accept help from one's friend (MM/DV 6:471; LE 204-205; cf. Paton 1993, pp. 140-142).

The most that one can achieve is what Kant calls "moral friendship," the friendship of disposition: "the complete confidence of two persons in revealing their secret judgments and feelings to each other, as far as such disclosures are consistent with mutual respect" (MM/DV 6:471). Kant's moral friendship is prized for being an aid in self-disclosure with no other practical ends (Veltman 2014. p. 281). The world is seen as a treacherous place full of deceit and betrayal, and it is only in friendship one is able to overcome "the constraint and the distrust man feels in his intercourse with others, by revealing himself to them without reserve" ( $L E$ 206). Friendship, in a word, is "man's refuge in this world from his distrust of his fellows, in which he can reveal his disposition to another and enter into communion with him" ( $L E$ 207). The perilous nature of the world, for Kant, in a sense has painted each of us into a corner of social isolation. Friendship is the saving grace that one can count on for a completely unreserved self-disclosure. Unlike perfect friendship which is an unattainable idea, moral friendship "is not just an ideal but (like black swans) actually exists here and there in its perfection" $(M M / D V$ 6:472). Moral friendship is a rare, natural phenomenon like black swans; it offers us a safe passage way to reveal our innermost self hidden from this hostile world of deceit and betrayal. But even so, Kant 
recurrently warns against a complete self-disclosure, since "it is unwise to place ourselves in a friend's hand completely" ( $L E$ 208; cf. $M M / D V$ 6:472).

Kant's skeptical doubt and cynicism towards the possibility of friendship stands in stark contrast with the exaltation of Greek philia, erotic or otherwise. Friendship now is no longer the most necessary external good, nor is it wise to attempt the actualization of mutual indwelling where two souls become transparent to one another. Moral or not, friendship, in Kant's mind, is a dangerous engagement where deceit and betrayal is always possible now or in the future, as Kant laments, "Among men there are but few who behave according to principles-which is extremely good" and this is even more so in the case of the fair sex: "I hardly believe that the fair sex is capable of principles, and I hope by this not to offend, for these are also extremely rare in the male" (Obs. 74, 81).

But in spite of it all, there is a subtle effort to revive both Kantian friendship and marriage (Denis 2001; Papadaki 2010). As Lina Papadaki writes in her defense of Kant, "The account of marriage, I believe, can and should be rescued from Kant's no longer acceptable views on gender. Setting aside Kant's views on the natural differences between men and women, and assuming equality and reciprocity between two spouses can lead to the creation of a true unity of will: one that is represented and controlled equally by both spouses" (288). Citing Charlotte Witt's 1996 lecture on "How Feminism is Re-writing the Philosophical Canon," Papadaki concurs with Witt in saying that we can take those philosophers who are accused of misogyny as holding a mistaken view about women and men and then safely ignore those view. For "[o]nce we set aside their views on gender, their theories can provide fuel for feminist thought" (Papadaki 294). In other words, it is conceptually possible to separate the philosopher's textual misogyny from his overall theory and that separation works to benefit feminist theorizing.

If a philosopher, like Kant, who holds overtly sexist views-not to mention his abhorrent racist views where, for instance, having a darker skin tone by itself is a clear indication of one's stupidity (Obs. 114; also see Of the Different Human Races; Physical Geography; Anth.; cf. Bernasconi and Lott 2000; Bernasconi 2002)—could be redeemed, then non-Western philosophical traditions such as Confucianism that are present with no more textual misogyny could, in principle, also be revived in a feminist image as well. However the feminist's re-appropriation often times stops at the door of the western canons. Overt textual misogyny in non-Western traditions is regularly cited as the ground for exclusion from feminist theorizing (Held 2006; Noddings 2010). But as one can see above, Kant's overt textual misogyny did not seem to preclude itself from the feminist possibility of theoretical re-appropriation. After all, Papadaki's 2010 piece in defense of Kant's views on marriage and friendship was published in Hypatia: A Journal of Feminist Philosophy, whose journalistic mission, as said in the title, is to advance feminist philosophy!

The point here, however, is not so much to point out the obvious double standard in dealing with western and non-Western traditions, or to expose some sort of insidious, subconscious cultural hierarchy in the feminist re-appropriation of the cannons. As Robin May Schott argues back in (2003), western feminists by and large have gone through and done with the phase of negative critiques of Western canons and are now much more engaged in the phase of positive construction of 
feminist theories emerged out of the ashes of western canonical texts (46). Here I am arguing for the same move for Confucian canonical texts as well. It is a move that does not linger on the negative rejection or superficial critique of sexist Confucian tradition, but one that takes the next bold move into the unknown, yet constructively imagined, theoretical horizon of Confucianism made in a feminist image. In the following we will take a creative journey into the hybridity of Confucian you with a blend of Greek philia as a feminist reconstituted spousal relationship in which spouses are true friends to one another united in both their bodies and souls for the sake of a mutually flourishing, good life without the pitfalls of absolute equality. But first, we will take a conceptual journey into the evolution of the Chinese concept of you 友.

\section{The evolution of You 友 from kinship love to virtuous fellowship}

As noted earlier, the Greek concept of philia has a much wider scope than what is conventionally understood in the modern concept of peer friendship and this is true for the Chinese as well. The ancient Greek's blurring of kinship line on one end and civil/political association as well as erotic attachment on the other in the discussion of philia can also be found in the Chinese concept of you 友. The picture graph for you 友 first found in the oracle-bone inscriptions of the Shang period (15th century $\mathrm{BCE}$ ) is either composed of two left or right hands facing the same direction: 㕛 (a pair of right hands) and 拜 (a pair of left hands) denoting a friendly pair working together (Vervoorn 2004, p. 6; He 2007, p. 293; Ames 2011, p. 118). And this sort of friendly association as found in the bronze inscriptions from the Western Zhou period (1045-1771 BCE) signifies kinsfolk; in the ancient clan-based political system, “you" 友 is used to refer to the fraternal bonds between brothers, father-son and ruler-subject.(Vervoorn 2004, p. 4; He 2007, pp. 292-293; Huang 2007, p. 4). For instance, in the Book of Documents (尚書 Shujing), one of the oldest texts in the Chinese Five Classics that holds the earliest records of dynastic history, the term you 友 is consistently used in conjunction with brotherly love and friendly political alliance (Shujing, "Dagao"; "Shaogao"; "Mushi”; "Kanggao"; and "Junchen"; cf. Vervoorn 8-9). ${ }^{1}$ In another Chinese Classic, the Book of Songs (詩經 Shijing), the term you 友, in addition, also occurs in the context of courtship and coupling (Shijing, Song 1; Song 165; cf. trans. Waley 1996; Vervoorn 9-12). ${ }^{2}$ In other words, the concept of friendship in ancient times covers a lot more grounds than the modern concept of voluntary, peer friendship.

As noted above, in ancient times, the term you 友, among other things, also signifies fraternal/brotherly love. With its ancient fraternal/kinship connection, you

\footnotetext{
"See Shujing尚書, “Dagao大誥”: “肆予大化誘我友邦君”; “Shaogao 召誥”: “予小臣敢以王之仇民百君子越友民”; “Mushi 牧誓”: “嗟! 我友邦冢君”; “Kanggao 康誥 封, 元惡大憝, 知惟不孝不友 and “兄亦不念鞠子哀, 大不友于弟”; “Junchen 君陳惟孝友于兄弟, 克施有政”; cf. trans. Legge.

${ }^{2}$ See Shijing 詩經, Song 1關睢: 參差荇菜、左右采之。窈察淑女、琴瑟友之; Song 165伐木: 伐木丁丁、鳥鳴嚶嚶。出自幽谷、遷于喬木。嚶其鳴矣、求其友聲。相彼鳥矣、猶求友聲; cf. trans. Waley.
} 
友 is also closely related to the foundational virtue of xiao 孝. As said in the Book of Songs, Zhang Zhong is praised for being xiao and you (張仲孝友) (Shijing, Song 177). Being conjoined with xiao 孝, you 友 obviously is seen here as an exalted virtue as well. Furthermore, xiao 孝 and you 友 are not just familial virtues; they are pre-requites for effective governing. As said in the Book of Documents, "Being xiao and you with your brothers (孝友于兄弟), you can display these qualities in the exercise of government" (Shujing, “Junchen"). In the ancient clan-based political system, it makes sense to conflate familial and political virtues. For one's brother, in all likely account, is also one's political ally and being filial 孝 (xiao) to one's parents and being brotherly 友 (you) are qualities required for one's political power.

But as the dissolution of the centralized system of Zhou gives way to individual semi-autonomous states during the Spring and Autumn period (770-476 BCE), a time when Confucius (551-479 BCE) espouses his socio-political philosophy, the virtue of you 友, a mutually beneficial association for a shared task at hand, begins to take root beyond kinship. The opportunity to serve at semi-autonomous regional courts begins to widen as each state competes with one another for domination. As it is well known, Confucius along with his disciples traveling from state to state for decades in search of a receptive ruler is a case in point. To park take in governance is no longer limited to the hereditary clan of a fortunate few. Confucius, the son of a lowly concubine, is also on the move to seek political opportunities. One can imagine there are many like Confucius and the opportunity for friendly association beyond one's kin also increases as these wondering scholarly-knights 游士 travel from state to state to advocate for their own ideal political visions.

Confucius's wondering scholarly-knight youshi 游士 in search of a virtuous fellowship with the ruler is most clearly delineated by Mencius who repeatedly points out that virtue trumps hereditary positions and social factors such as age, rank, and family origin; furthermore, the proper way to build friendship between the socially superior and the subordinate, such as emperor and commoner and aristocrat and his retainer, is to bypass those social factors (Mencius 2B2, 5A4, 5B3, 5B7, 7A43; cf. trans. Lau 1970). To Mencius, deference is not just applied to the socially superior; the way that the superior defers to his subordinate is called honoring the virtuous (5B3). In other words, this Mencian friendship model is a direct inversion of the Aristotelian model in that, for Mencius, the commoner/minister is the one who is conceived of as in possession of virtue and the one that the ruler/aristocrat should seek to befriend without relying on the advantages of his nobility. In short, unlike Aristotle, Mencius sees that virtuous friendship rests on the social subordinate. In this way, virtue is seen as a social equalizer where the ruler and minister or the aristocrat and retainer are called friends. Indeed, transforming the concept of you 友 from mutually beneficial kinship love to a virtuous fellowship applicable not just to peer scholarly-knights, but also to the political relationship of ruler and minister is a specific contribution of the Confucian to the evolution of you 友.

As the class of wondering scholarly-knights rises, you 友 is also recognized as someone that the scholar-knight shi 士 is especially in need of. But more importantly, for the Confucian, you 友 also serves as a moral compass for peer scholar-knights shi 士 in the social/political realm. As said in the Xiaojing 孝經 
(Book of Filial Reverence), Confucius is quoted as saying that "Of old, an Emperor had seven ministers who would remonstrate with him (爭臣), even if he had no right method of governing, he did not lose the empire;...if the scholarly-knight had friends who would remonstrate with him (士有爭友), a good name would not cease to be connected with him; and if the father had sons who would remonstrate with him (父有爭子), he would not behave reprehensively" (Xiaojing, Ch. 15; cf. trans. Rosemont and Ames 2009). Or what is the same, as said in the Kongzi Jiayu 孔子家 語, Confucius is repeatedly quoted as saying that having zhenyou 爭友 is a moral imperative for $s h i$ 土, just as having zhenchen 爭臣 for the ruler and zhenzi 爭子 for the father. ${ }^{3}$

To be a zhenchen 爭臣 to the ruler, the shi 士 must strive to be a mentor (shi 師) or friend (you 友), not just a functional vessel (cf. Analects 2.12; cf. trans. Ames and Rosemont 1998). It is something that Confucius and his disciples are aspired to be. As Sima Qian, the grand historian of Han writes in the "Biography of the Confucian": "After the death of Confucius, his 70 disciples scattered and wondered among different aristocrats; the great ones become a teacher of the minister, and the lesser ones become a friend of the scholarly-officer” (大者為師傅卿相, 小者友教 士大夫) (Shiji, “Rulin liezhuan"). In fact, during the Han dynasty both teacher (shi 師) and friend (you 友) are also formalized into the highest two ranks of the official post. As said in the Han text, Xinshu 新書 (New Book), “The Lord's official has six ranks: the first is called teacher ( $s h i$ 師), second friend (you 友), third great minister (大臣), fourth left-right hand assistant (左右), fifth imperial attendant (侍御), sixth servant and labor (廝役)” (Xinshu, Chap. 8: “Official”). Being the ruler's teacher or friend is obviously a much more exalted rank than being a mere servant, and those rulers who surround themselves with teachers and friends will also be much more prosperous as well. As the same text continues to say, "Therefore those with teachers for the state become an emperor (故與師為國者, 帝); those with friends become a lord (與友為國者, 王); ...those with imperial attendants might survive or might perish (與侍御為國者, 若存若亡); and those with servants and labors are sure to perish (與廝役為國者, 亡可立待也) “(Xinshu, Chap. 8: “Official”). In other words, for the Confucian, the state is more than just a hierarchical bureaucracy staffed with servants to execute top-down orders; rather, it is a moral enterprise where the ruler and minister are bound in a virtuous mentorship and friendship.

For the Confucian, friendship is made for mutual moral perfection, but unlike the Aristotelian perfect friendship between two superior men of equal social status and character, Confucian virtuous fellowship doesn't require a sense of symmetrical equality between friends. As noted earlier, for Mencius, it is a political imperative for the ruler to seek out and befriend the scholarly-knight to form a virtuous mentorship/friendship and in making friends, one should not rely on the advantages of one's nobility. In other words, unlike Aristotle, for the Confucian, virtue and social nobility don't need to go hand in hand, nor does equality in friendship need to rest on superiority (that is, the proportional equality between two social unequals, in

\footnotetext{
${ }^{3}$ See Kongzi Jiayu, “三恕 (Three Reciprocity)”: “父有爭子, 不陷無禮; 士有爭友, 不行不義”; “六本 (Six Bases)”: “君無爭臣, 父無爭子, 兄無爭弟, 士無爭友, 無其過者, 未之有也”; “子路初見 (Zilu’s First Encounter)”: “夫人君而無諫臣則失正, 士而無教友則失聽”.
} 
Aristotle's view, can only be restored by tilting in favor of the superior). Indeed, there is no such presumption of equality in Confucian virtuous fellowship.

Furthermore, unlike the Kantian perfect friendship, Confucian virtuous fellowship is not built based on the unattainable idea of absolute equality of respect and love between friends. Confucian virtuous friendship is made for us mortals, who live among the multitude with different interests and levels of ability. There is no litmus test of equal ability or equal respect and love before mentorship/friendship can be found. Mentorship/friendship can come from anyone, if one seeks the path of moral perfection. As Confucius says, "Three people strolling together, I am bound to find a teacher (三人行, 必有我師焉); choosing the good to follow and amend my way when encounter the bad" (Analects 7.22). In other words, both the good and the bad conduct found in one's company serve as a reminder for one's self in modeling after or in amending one's shortcoming.

Although Confucius does repeatedly says "Don't befriend those who are unequal to oneself (冊友不如已者)”, this passage is immediately followed by the imperative that "When one is at fault, don't fear to amend it" (Analects 1.8, 9.25). Obviously, the self is assumed to be morally imperfect and hence the need to amend one's way is an imperative. In light of one's moral imperfection, the previous injunction cannot be interpreted as saying that one's friends must be as morally prefect as oneself. Instead what one needs is another pair of eyes and ears to provide critical feedback to one's self in amending one's shortcomings. And the duty of friendship is to provide that critical feedback in order to lead one another to moral perfection. As Confucius says, “friends are critical and demanding with one another (朋友切切, 偲偲), but amicable with their brothers" (Analects 13.28). Or what is the same, as said in the Mencius, “Demanding goodness is the way of friendship (責善, 朋友之 道也); but being so demanding between father and son is the greatest injury to the kindness prevailing between them" (4B30). In short, that critical attitude is the mark of friendship, in comparison to other types of intimate relationship such as parentchild or siblings who are bound to one another first and primarily by mutual affection.

What is essential in sustaining Confucian friendship is the mutual commitment to moral perfection. What friends must share is to stay on the same virtuous path to moral perfection, and "those whose paths are different," as Confucius says, "cannot lay plan for one another” (道不同, 不相為謀) (Analects 15.40). Or as Xunzi puts it, "A lord must be cautious in selecting a minister and commoner in selecting a friend. Friends are those render mutual support (友者, 所以相有也). If their paths are different, how can they have mutual support? (道不同, 何以相有也)” (Xunzi, Chap. 27; cf. trans. Knoblock 1999; Hutton 2014). Friends are those who walk in the same virtuous path, but they need not be already in the possession of prefect virtue or even equal in virtue. As said in the Liji (Book of Rites), "The scholar has those with whom he agrees in aim, and shares the same direction (合志同方), manages the same path, and uses the same methods (營道同術); when they stand on the same level with him, he rejoices in them; if their standing be below his, he does not tire of them;... if they proceed in the same path with him, he goes forward with them, if not, he withdraws (同而進, 不同而退). This is what making friends is (其交友有如 此者)” (Liji, “Ruxing”). In other words, one's friends' continuous commitment to 
walking in the same path of moral perfection is what sustains Confucian friendship, not their equal ability.

But of course, there is a limit as to how far one is able to move friends to the direction of goodness. “Doing one's utmost and lead them to goodness (忠告而善道 之)" as Confucius says, is the way to treat one's friends, but "if this doesn't work, then stop; don't disgrace oneself" (Analects 12.23). Moral receptivity and mutual support in friendship is essential. As said precisely in the Zhonglun 中論 (Middle Discourse), a Han text, "To speak of the obligations of friendship, it lies in the cutting and making one upright so as to rise in the way of goodness (言朋友之義務, 在切直以升於善道者也); therefore the junzi doesn't befriend those who are unequal to oneself (故君子不友不如已者)...those who are unequal to oneself require oneself to make them upright (不如已者須己而植者也). But then too busy in supporting others, who is going to reciprocate me? (然則扶人不暇, 將誰相我 哉)" (Zhonglun, "Guiyan"). As pointed out earlier, the metaphor of "mutual cutting and polishing (相與切硅)" is often times applied to friendship and hence what must be equal between friends for the Confucian is the commitment to mutual moral perfection. In short, mutual support in ascendency to moral goodness is what friendship is for.

\section{The hybridity of Confucian You 友 as spousal relationship}

So how does modern spousal relationship fit into this long conceptual evolution of friendship both East and West? As noted earlier, if marriage is no longer seen as a necessity for a woman in exchange for male guardianship or financial support, then for what does one get marry? And if child-bearing and rearing is no longer seen as the natural end of marriage ordained by the divine, then what is it that binds marriage together till death do we part? In short, what is a spouse for?

Just as true in the West, in the Confucian tradition, the spousal relationship is first and primarily one of functional utility. Although it is true that in numerous didactic texts such as the Biographies of Exemplary Women and Guifan as well as in each dynastic historical records women are exalted for their virtuous achievement beyond their functionary roles in the household, marital relation nevertheless is first and foremost marked by functional differentiation. As it is plain in the doctrine of five social relations, unlike all other four social relations-father-son, ruler-minister, older-younger, and friends-each is marked by a definitive virtue, husband-wife relationship is instead marked by bie 别, the division of labor, a functional differentiation for a task at hand. Conventionally women are in charge of the nei (inside) and men the wai (outside). And as it is prevalent in many Confucian texts, most obviously stated in the Liji, women's education and duties are limited to house duties and managements regardless of their actual literary achievement and virtuous ability (for nei/wai distinction and didactic texts for women, cf. Rosenlee 2006, Chaps. 4-5). In other words, women might be talented beyond their proper sphere of nei and their virtue on par with their male counterparts as many talented and virtuous women in history, most notably Ban Zhao of Han, have demonstrated, women's proper sphere nevertheless continues to be defined by nei, a realm of 
domesticity. For even with all her accomplishments in the court of Han, Ban Zhao was never granted an official title in the outer court and her contribution to the completion of dynastic history was also unrecognized (cf. Rosenlee 2006, Chap. 6). And such an overt omission of women's actual achievement beyond the realm of nei can only be understood in the context of nei/wai binary where each gender is defined first and foremost by its functional sphere. A woman, confined to the realm of nei, hence is essentially a functional vessel for household management first and foremost, a sort of thing that Confucius says a well-rounded junzi should not be (君 子不器) (cf. Analects 2.12). So the reductive aspect of marriage where women become functionary and auxiliary to the husband, whose true calling lies in the expansive realm of wai, must be overcome. Marriage is a perpetual union, but that union must be built based on something more sublime than a mere contractual exchange of functional goods and something more wholesome than a one-sided glory of men.

Within the Confucian tradition, I propose replacing the spousal relationship with friendship, where two people are bound by their mutual commitment to moral perfection in which each is supported by the other in their ascendency to the way of moral goodness. This is neither a transcendent move nor an unachievable idea. Moral goodness for the Confucian is squarely an earthly one, one that emerges from as well as is an embodiment of the ideal of each existential human relationship. Unlike Plato, for the Confucian, there is no transcendent realm of the form that one ascends to with one's winged lover; there is only the earthly harmony in the ever more widened web of human relationships. And unlike Aristotle, the Confucian does not prioritize pure contemplation over practical virtue. The glitter allure of the transcendent idea or the divine realm is not what the Confucian moral goodness aims at and thereby not what Confucian virtuous fellowship is there for either (cf. Ames 2011). Confucian you 友 is made for us mortals for everyday living, since it is a sort of moral relationship that requires neither an Aristotelian sense of symmetrical equality between friends, nor a Kantian sense of unrealizable absolute equality between love and respect. A good friend for the Confucian is not a mere copy of one's virtuous self, a black swan, or a divine grace, but a necessary component in the making of one's moral sense. In the modern spousal relationship, Confucian earth-bound friendship should serve as a model in order to replace the old paradigm of marriage as an exchange of functionary, external goods, or as a union for the one-sided glory of men. Spouses should be you 友 and their blessed, perpetual union is a testament of their mutual commitment to walking in the same path of moral perfection in which each cuts and polishes the moral sense of the other so that they might both become something greater than they once were and their ascendency to the way of moral goodness is the result of their perpetual friendship bond. Moral goodness, in other words, is an internal good of friendship and should also be an internal good of modern marriage.

At the same time, spousal relationship is a perfect site for Confucian you 友, since their mutual commitment to walking in the same path is perpetual. Walking in the same path, in marriage or in friendship, however doesn't require sameness in thought or deed. Spouses, no less than a junzi, should be affable for sure, but not monolithic with one another (君子和而不同) (cf. Analects 13.23). For moral 
rectitude, that characterizes the conduct of a junzi as opposed to profit-seeking for a petty person (君子喻於義, 小人喻於利) (cf. Analects 4.16), is also what binds friends together. As said perfectly in the Caizhonglangji 蔡中郎集, a Han text, “In covering the way of friendship, when there is moral rectitude, friends are united and when there is no moral rectitude, friends are apart (蓋朋友之道, 有義則合, 無義則 離)” (Caizhonglangji, “Zhengjiaolun”).

What is more is that the sexual nature of the marital union helps to strengthen, not diminish moral rectitude in marriage, since lovers who are drawn by their passionate love and affection for one another make promises to form an eternal union in which each wishes the other well and loves not just the body but also the soul. Unlike Aristotelian perfect philia that neglects the power of eros in philoi's shared life, Plato's erotic philia has much to teach us; lovers who are bound in their love of the body should also be bound in their mutual love of the soul as well, and that erotic madness is what first propels us mere mortals to elevate our temporary bodily love to the sublimity of the eternal love of the soul. The shared life between philoi in marriage in which eros is a part is ever more complete, since philoi share all aspects of life, let it be erotic or intellectual, mundane or spiritual. Eroticism forms no small of a wholesome marriage, and hence the philosophical aversion towards eroticism leads to an incomplete understanding of what is possible in forming an even more perfect union in marriage. Sex is not just a contractual, functionary tool for mutual bodily pleasure as Kant infamously characterizes it; nor is it solely for the divinely ordained natural end in marriage which is child-bearing as Augustine and Aquinas have envisioned it. Eroticism, no less than the intellect, also forms part of one's natural self, and marriage, a perpetual union, is the perfect site for one's erotic expression for another. One's erotic passion for another, as Plato teaches us, can also be sublime and soul enriching, since it propels us to seek an ever more completely "mutual indwelling" in one another, not just in the body, but also in the soul through the everlasting loop of love and backlove in the eyes of lovers. In short, propelled by eros, lovers lone to be part of each other's soul and thereby uplift their souls to moral goodness as well. Or, what is the same as shown in the Chinese Classic of the Book of Songs, the joy of courtship and coupling is also a manifestation of you 友.

Spouses, no less than friends, who share a life together, cannot build a shared life with the template of 50/50 equal split as some feminists have advocated. Yes, unduly sacrifice demanded of women in the role of wife and mother impedes women's ability to live a wholesome life in which they can also become greater than they once were before marriage. But the template of absolute equality is unattainable just as Kant's insistence on the absolute equality between love and respect in friendship, and the result is cynicism or resignation. In a good relationship of any kind, there is sure a sense of reciprocity and mutuality, but unlike in a contractual transaction, in a good marriage or friendship, the sort of reciprocity and mutuality involved is not marked by numerical equality in a definitive term. It is a faithful understanding of and a persistent effort in realizing the enduring goodness in one another. For what is especially appealing about friendship is the penetrating understanding that two good friends have of one another, and that faithful understanding of one another is what enables friends to transcend the temporal 
needs to repay in kind and in a timely manner that an ordinary dealing in everyday life demands. Friends are faithful to one another, not in a sense of blind obedience, but in a way that insists on the enduring goodness in one another, a sort of goodness that is both actual and potential. And by being faithful to one another in this way, friends not only see what is good in one another, but also help realize what else is possible through thick and thin. Looking at marriage in this way, to mandate a 50/50 equal split makes marriage not only seem superficial and contractual, but also contrary to what is required in an enduring friendship, not to mention its unattainability.

\section{Concluding reflections}

So in response to the question of "What is a spouse for?" the answer is friendship. And in rethinking spousal relationship as a hybridized Confucian you 友 with a blend of Greek philia, the functionary and oppressive aspects of marriage are thus made incompatible with this friendship based marital union. At the same time, by incorporating marital relationship into friendship, the concept of friendship is made ever more perfect. Just as in a good marriage both spouses are lifted up by their marital union, the union between marriage and friendship uplifts both conceptually as well. Spouses, in short, should be best friends who lead one another to moral goodness through mutual cutting and polishing one's critical moral sense with penetrating understanding and enduring faith, and the spousal relationship, in turn, is also the best friendship that is perpetual and complete in its form and content by building a truly shared life with all aspects of human capacities, eros and all. Or what is the same, the joy of courtship and coupling is also a manifestation of you 友. A feminist marriage, as I see it, should be a marriage of moral friendship and passionate love, in which the friendly pair of committed hands goes both way and in which moral goodness is strengthened, not diminished by eros or the joy of courtship and coupling. It is indeed a new conceptual paradigm of marriage that is made in a Confucian image for feminists; it is also a practical feminist paradigm that we mortals can strive for and realize in our human all-too-human life.

As a mother and wife in a household with two professionals, I too feel the strain in navigating through the contour of a married life. It is a journey like no others, but it is also a journey that tests the limits of my feminist commitments to gender equity. How far and how much of a sacrifice made on behalf of an equally competent adult is reasonable without being at risk of moral degradation? And when and how should one demand reciprocity without at the same time degrading the marital union into an obligatory business transaction? The liberal feminist model of equal give and take is inadequate; there is no score sheet to keep track of and the calculating nature of an equal split runs counter to the intimate nature of marriage. What we need is not more unrealizable ideals in our flawed life, or to advocate for a complete evacuation from motherhood and marriage that evades the problem instead of solving it. By proposing a hybridized Confucian you 友 in place of spousal relationship, I intend to provide a practical conceptual tool that enables women to live a feminist life as fully as possible as they embark on their journey of 
a perpetual marital union. A Confucian you 友 based marital union is a union without gender-based division of labor nor gender based hierarchy, but at the same time, this friendship model offers women the flexibility of charting their own course of what constitutes a faithful and enduring spousal friendship. There is no set formula for the sacrifice and reciprocity in friendship, and neither should it be in marriage. But in both cases, a heightened sense of moral vigilance is required, since that is what friendship is for in the first place and that should also be the case for marriage as well. Marriage is a friendship with all its perfection, eros and all.

\section{References}

Allen, J. 1984/1993. Motherhood: The annihilation of women. In Alison M. Jaggar \& S. P. Rothenberg (Eds.), Feminist frameworks: Alternative theoretical accounts of the relations between women and men (3rd ed., pp. 380-385). New York, NY: McGraw-Hill.

Ames, R. T. (2011). Confucian role ethics: A vocabulary. Honolulu, HI: University of Hawaii Press.

Ames, R., \& Rosemont, H. Jr. Trans. (1998). The analects of confucius: A philosophical translation. New York, NY: Random House

Barnes, J. (Ed.). 1984/1995. The complete works of Aristotle (Vol. 2). Princeton, NJ: Princeton University Press.

Bernasconi, R. (2002). Kant as an unfamiliar source of racism. In K. W. Julie \& T. L. Lott (Eds.), Philosophers on race: Critical essays. New York: Blackwell.

Bernasconi, R., \& Lott, T. L. (2000). The idea of race. Indianapolis: Hackett.

Caizhonglangji 蔡中郎集. http://ctext.org/caizhong-langji. Accessed on August 10, 2015.

Card, C. (1996). Against marriage and motherhood. Hypatia 11.3(Summer): 1-23.

Card, C. (2002). The atrocity paradigm: A theory of evil. Oxford: Oxford University Press.

Card, C. (2007). Gay divorce: Thoughts on the legal regulation of marriage. Hypatia 22.1(Winter):24-38.

CNN. (2015). Still missing: Female business leaders. In M. Egan, March 24. http://money.cnn.com/2015/ 03/24/investing/female-ceo-pipeline-leadership. Accessed on June 19, 2015.

Connolly, T. (2012). Friendship and filial piety: Relational ethics in Aristotle and early confucianism. Journal of Chinese Philosophy, 39(1), 71-88.

Cooper, J. M. 1997. Plato: Complete Works. Hackett.

Crittenden, A. (2001/2010). The price of motherhood: Why the most important job in the world is still the least valued. New York, NY: Picador.

Denis, L. (2001). From friendship to marriage: Revising Kant. Philosophy and Phenomenological Research, 63(1), 1-28.

Fullam, L. (2012). Toward a virtue ethics of marriage: Augustine and Aquinas on friendship in marriage. Theological Studies, 73, 663-692.

Fuller, T. (2008). Plato and Montaigne: Ancient and modern ideas of friendship. In J. von Heyking \& R. Avramenko (Eds.), Friendship and politics: Essays in political thought (pp. 197-213). Notre Dame, IN: University of Notre Dame.

Goldthwait, J. T. Trans. (1960). Kant: Observations on the feeling of the beautiful and sublime. Berkeley, CA: University of California Press

Gregor, M. (Ed.). (1996). Kant: The metaphysics of morals. New York, NY: Cambridge University Press.

He, Y. (2007). Confucius and Aristotle on friendship: A comparative study. Frontiers of Philosophy in China, 2(2), 291-307.

Held, V. (2006). The ethics of care: Personal, political, and global. New York, NY: Oxford University Press.

Hochschild, A. R. (1989). The second shift. New York, NY: Quill.

Huang, M. W. (2007). Male friendship in Ming China: An introduction. Nan Nu, 9, 2-33.

Hutton, Eric L. Trans. 2014. Xunzi: The Complete Text. Princeton, NJ: Princeton University Press

Infield, L. Trans. (1930/1963). Kant: Lectures on Ethics. Indianapolis: Hackett.

Knoblock, J. Trans. (1999). Xunzi (Vol. 2). Beijing: Foreign Languages Press. 
Kongzi Jiayu 孔子家語. http://ctext.org/kongzi-jiayu. Accessed on July 27, 2015.

Lau, D. C. Trans. (1970). Mencius. London: Penguin Books.

Liji 禮記 (Book of Rites). http://ctext.org/liji. Accessed on July 29, 2015.

Louden, R. B. Trans (Ed.) (2006). Kant: Anthropology from a pragmatic point of view. New York, NY: Cambridge University Press

Mahoney, P., \& Williams, L. M. (1998). Sexual assault in marriage: Prevalence, consequences, and treatment of wife rape. http://www.ncdsv.org/images/nnfr_partnerviolence_a20-yearliteraturereview andsynthesis.pdf. Accessed on June 18, 2015.

Mahowald, M. B. (1978/1994). Philosophy of woman: An anthology of classic to current concepts (3rd ed.) Indianapolis, IN: Hackett.

McLaughlin, E. (2000). Equality of souls, inequality of sexes: Women in medieval theology. In J. P. Sterba (Ed.), Ethic: Classical western texts in feminist and multicultural perspectives. New York, NY: Oxford University Press.

Mill, J. S. (1869/2003). In J. P. Sterba (Ed.) The subjection of women in social and political philosophy: Classical western texts in feminist and multicultural perspectives (3rd ed., pp. 340-351) Belmont, CA: Wadsworth/Thomson Learning.

Murr, D. E. (2014). Philia in plato. In G. Gurtler \& S. Stern-Gillet (Eds.), Ancient and medieval concepts of friendship (pp. 3-34). Albany, NY: State University of New York.

New York Times. (2012). Jobs where gender segregation persists. In B. Marsh, September 30. http://www. nytimes.com/imagepages/2012/09/30/opinion/30coontz-gr1.html. Accessed on June 23, 2015.

Nichols, M. P. (2009). Socrates on friendship and community: Reflections on Plato's symposium, Phaedrus, and Lysis. Cambridge: Cambridge University Press.

Noddings, N. (2010). The maternal factor: Two paths to morality. Berkeley, CA: University of California Press.

Nussbaum, M. C. (1986). The fragility of goodness: Luck and ethics in Greek tragedy and philosophy. Cambridge: Cambridge University Press.

Obergefell et al. v. Hodges, Director, Ohio Department of Health, et al. 2015. Supreme Court of the United States, No. 14-556. Argued April 28, 2015-Decided June 26, 2015. http://www. supremecourt.gov/opinions/14pdf/14-556_3204.pdf. Accessed on June 26, 2015.

Okin, S. M. (1989). Justice, gender, and the family. New York: Basic Books.

Pakaluk, M. (Ed.). (1991). Other selves: Philosophers on friendship. Indianapolis, IN: Hackett.

Papadaki, L. (2010). Kantian marriage and beyond: Why it is worth thinking about Kant on marriage. Hypatia, 25(2), 276-294.

Paton, H. J. (1993). Kant on friendship. In N. K. Badhwar (Ed.), Friendship: A philosophical reader. Ithaca, NJ: Cornell University Press.

Quinn, P. (1996). St. Thomas Aquinas and the Christian understanding of friendship. In O. Leaman (Ed.), Friendship east and west: Philosophical perspectives. London: Cruzon Press.

Rosemont, H. Jr., \& Ames, R. Trans. (2009). The Chinese classic of family reverence: A philosophical translation of the Xiaojing. Honolulu, HI: University of Hawaii Press

Rosenlee, L. L. (2006). Confucianism and women: A philosophical interpretation. Albany, NY: State University of New York Press.

Ruether, R. R. (2000). Misogynism and virginal feminism in the fathers of the church. In J. P. Sterba (Ed.), Ethic: Classical western texts in feminist and multicultural perspectives. New York, NY: Oxford University Press.

Salkever, S. (2008). Taking friendship seriously: Aristotle on the place(s) of philia in human life. In J. Von Heyking \& R. Avramenko (Eds.), Friendship and politics: Essays in political thought. Notre Dame, IN: University of Notre Dame.

Sandberg, S., \& Nell, S. (2013). Lean in: Women, work, and the will to lead. NewYork, NY: Alfred A. Knopf.

Schindler, J. H. (2008). A companionship of carita: Friendship in St. Thomas Aquinas. In J. von Heyking \& R. Avramenko (Eds.), Friendship and politics: Essays in political thought. Notre Dame, IN: University of Notre Dame Press.

Schott, R. M. (2003). Discovering feminist philosophy: Knowledge, ethics and politics. Rowman \& Littlefield.

Schwartz, D. (2007). Aquinas on friendship. New York, NY: Oxford University Press.

Sherman, N. (1997). Making a necessity of virtue: Aristotle and Kant on virtue. Cambridge, UK: Cambridge University Press.

Shiji 史記 (Historian's Records). http://ctext.org/shiji. Accessed on July 22, 2015. 
Shijing 詩經 (Book of Songs). http://ctext.org/book-of-poetry. Accessed on June 29, 2015.

Shujing 尚書 (Book of Documents) http://ctext.org/shang-shu. Accessed on June 29, 2015

Sim, M. (2007). Remastering morals with Aristotle and Confucius. Cambridge: Cambridge University Press.

Time. (2009). In N. Gibbs (Ed.), What women want now, Oct. 14. http://content.time.com/time/specials/ packages/article/0,28804,1930277_1930145_1930309-2,00.html. Accessed on June 24, 2015

Veltman, A. (2014). Aristotle and Kant on self-disclosure in friendship. In G. M. Gurtler \& S. Stern-Gillet (Eds.), Ancient and medieval concepts of friendship. Albany, NY: State University of New York Press.

Vervoorn, A. (2004). Friendship in ancient China. East Asian History, 27(June), 1-32.

Waley, A. Trans. (1996). The book of songs, Shijing: The ancient Chinese classic of poetry. New York, NY: Grove Press

Xinshu 新書 (New Book). http://ctext.org/xin-shu. Accessed on July 24, 2015.

Xinxu 新序(New Order). http://ctext.org/xin-xu. Accessed on July 22, 2015.

Yalom, M. (2001). A history of the wife. New York, NY: Harpercollins.

Zhonglun 中論 (Middle Discourse). http://ctext.org/zhong-lun. Accessed on July 29, 2015. 